\title{
Quantifying the
} Financial Benefits of Multifamily Retrofits

D. Philbrick, R. Scheu, and L. Brand Partnership for Advanced Residential Retrofit

January 2016 


\section{NOTICE}

This report was prepared as an account of work sponsored by an agency of the United States government. Neither the United States government nor any agency thereof, nor any of their employees, subcontractors, or affiliated partners makes any warranty, express or implied, or assumes any legal liability or responsibility for the accuracy, completeness, or usefulness of any information, apparatus, product, or process disclosed, or represents that its use would not infringe privately owned rights. Reference herein to any specific commercial product, process, or service by trade name, trademark, manufacturer, or otherwise does not necessarily constitute or imply its endorsement, recommendation, or favoring by the United States government or any agency thereof. The views and opinions of authors expressed herein do not necessarily state or reflect those of the United States government or any agency thereof.

Available electronically at SciTech Connect http:/www.osti.gov/scitech

Available for a processing fee to U.S. Department of Energy and its contractors, in paper, from:

U.S. Department of Energy

Office of Scientific and Technical Information

P.O. Box 62

Oak Ridge, TN 37831-0062

OSTI http://www.osti.gov

Phone: 865.576.8401

Fax: 865.576.5728

Email: reports@osti.gov

Available for sale to the public, in paper, from:

U.S. Department of Commerce

National Technical Information Service

5301 Shawnee Road

Alexandria, VA 22312

NTIS http://www.ntis.gov

Phone: 800.553 .6847 or 703.605 .6000

Fax: 703.605.6900

Email: orders@ntis.gov 


\title{
Quantifying the Financial Benefits of Multifamily Retrofits
}

\author{
Prepared for: \\ The National Renewable Energy Laboratory \\ On behalf of the U.S. Department of Energy's Building America Program \\ Office of Energy Efficiency and Renewable Energy \\ 15013 Denver West Parkway \\ Golden, CO 80401 \\ NREL Contract No. DE-AC36-08GO28308 \\ Prepared by: \\ D. Philbrick, R. Scheu, and L. Brand \\ The Partnership for Advanced Residential Retrofit \\ Elevate Energy \\ 322 S Green St, Suite 300 \\ Chicago, IL 60607 \\ NREL Technical Monitor: Stacey Rothgeb \\ Prepared under Subcontract KNDJ-0-40346-05
}

January 2016 
The work presented in this report does not represent performance of any product relative to regulated minimum efficiency requirements.

The laboratory and/or field sites used for this work are not certified rating test facilities. The conditions and methods under which products were characterized for this work differ from standard rating conditions, as described.

Because the methods and conditions differ, the reported results are not comparable to rated product performance and should only be used to estimate performance under the measured conditions. 


\section{Contents}

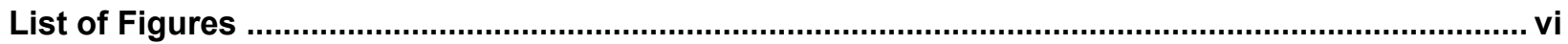

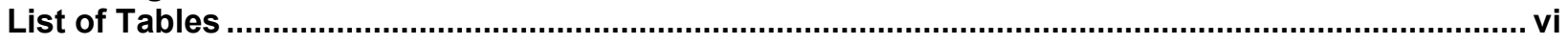

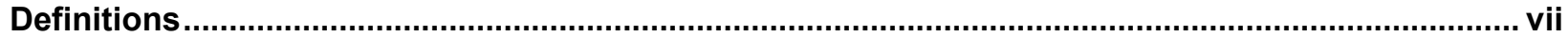

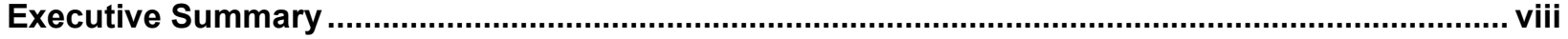

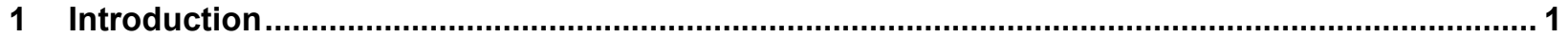

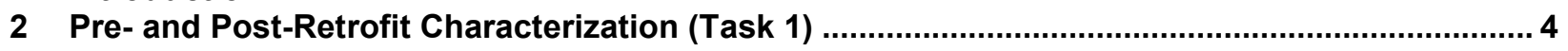

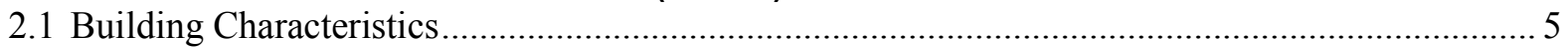

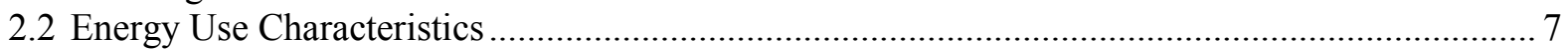

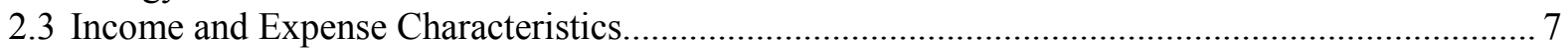

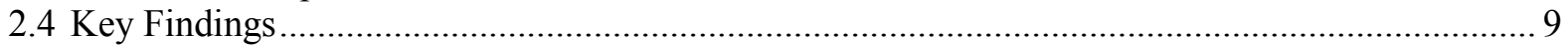

3 Comparison of the Chicago Buildings to National Financial Data Sets (Task 2) ......................11

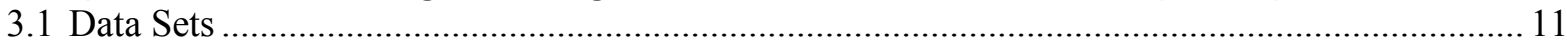

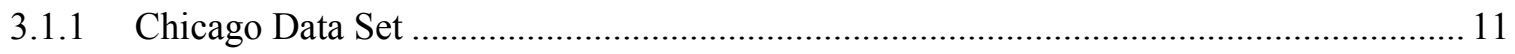

3.1.2 U.S. Department of Housing and Urban Development's Rental Housing Finance Survey ................................................................................................... 11

3.1.3 The National Apartment Association's Survey of Operating Income and

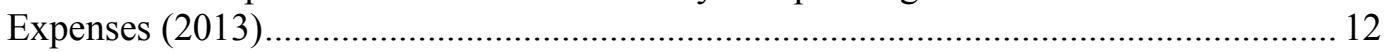

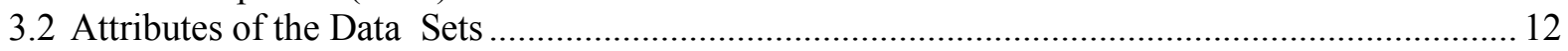

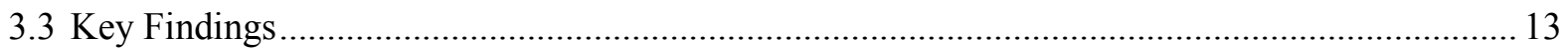

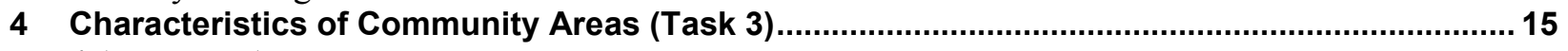

4.1 Data 15

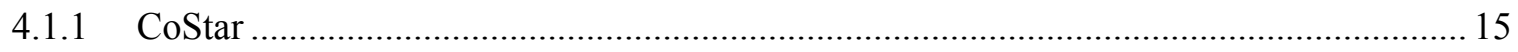

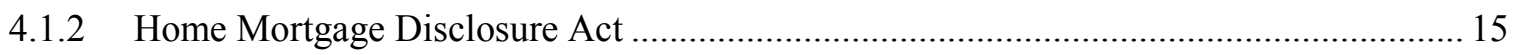

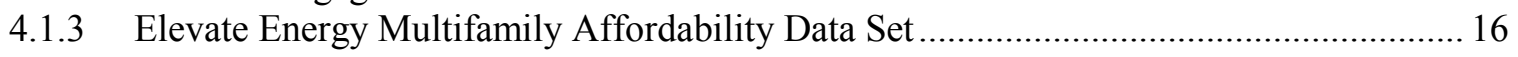

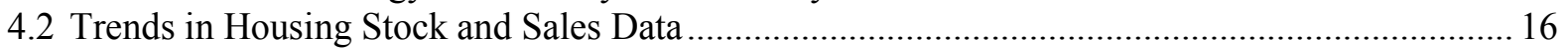

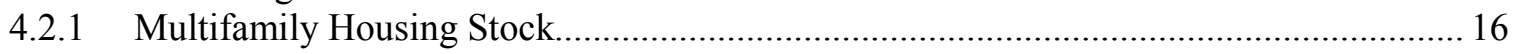

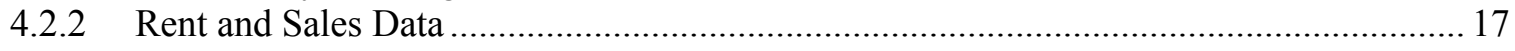

4.2.3 Housing Mortgage Disclosure Act Data .................................................................. 19

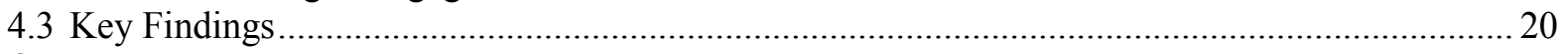

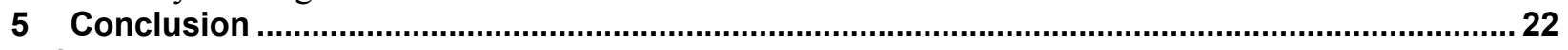

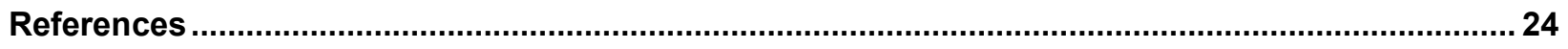

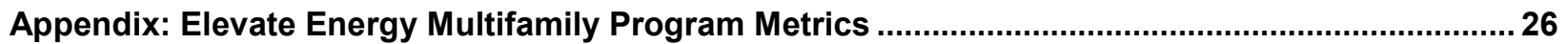




\section{List of Figures}

Figure 1. Locations of Task 1 buildings and corresponding communities ...................................... 5

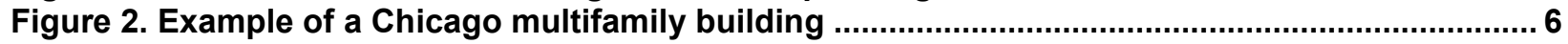

Figure 3. Annual expenses per unit for Chicago data set ............................................................ 12

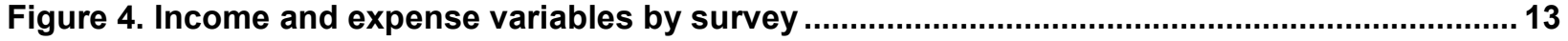

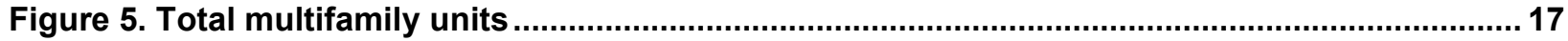

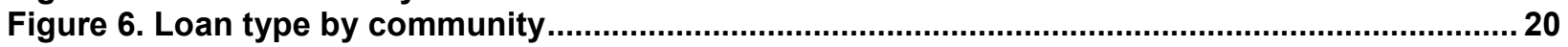

Unless otherwise noted, all figures were created by the Partnership for Advanced Residential Retrofit team.

\section{List of Tables}

Table 1. Descriptive Building Characteristic Statistics...................................................................

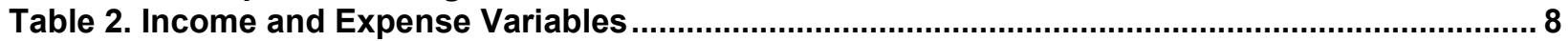

Table 3. Pre-and Post-Retrofit Annual Income and Expenses, Mean of Reported Data from 13

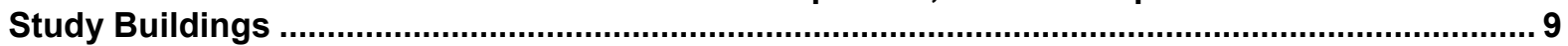

Table 4. Annual Financial Indicators per Unit for Each Data Set .................................................... 14

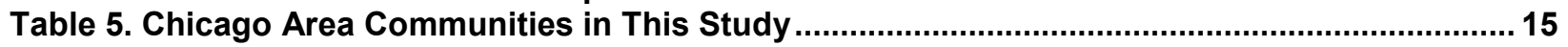

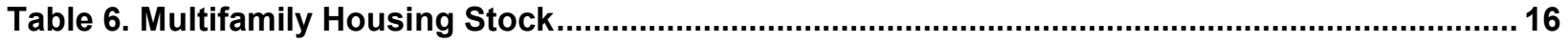

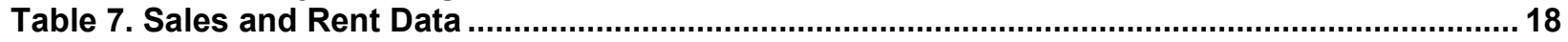

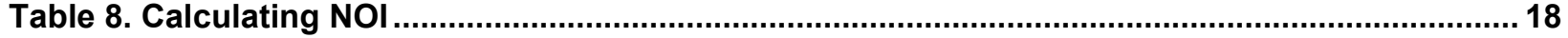

Table 9. Example of Cap Rate Decreasing with Energy Efficiency.................................................... 22

Unless otherwise noted, all tables were created by the Partnership for Advanced Residential Retrofit team. 


\section{Definitions}

Cap Rate

CIC

NAA

NOI

PARR

RHFS
Capitalization Rate

Community Investment Corporation

National Apartment Association

Net Operating Income

Partnership for Advanced Residential Retrofit

Rental Housing Finance Survey 


\section{Executive Summary}

Increasing the adoption of energy-efficient building practices will require the energy sector to increase its understanding of the ways that retrofits affect multifamily financial performance and how the lending and appraisal industries interpret those indicators.

The U.S. Department of Energy's Building America research team Partnership for Advanced Residential Retrofit analyzed building, energy, and financial program data as well as other public and private data to examine the relationship between energy-efficiency retrofits and financial performance on three levels: building, city, and community.

The project goals were to increase the data and analysis in the growing body of multifamily financial benefits work and to provide a framework for other geographies to produce similar characterization. The goals are accomplished through three tasks:

- Task 1: A pre- and post-retrofit analysis of 13 Chicago multifamily buildings

- Task 2: A comparison of Chicago income and expenses to two national data sets

- Task 3: An in-depth look at multifamily market sales data and the subsequent impacts of buildings that undergo retrofits.

Key findings include:

- The net operating income of buildings that had energy-efficiency improvements increased by $2.95 \%$ ( $\$ 55.96 /$ unit) byl year post-improvement.

- Rental incomes increased by almost $2.39 \%$ (\$227.48/unit) annually in the year after energy-efficiency improvements were completed.

- Utility costs are one of the largest multifamily building operating expenses in Chicago and nationally.

- National data sets of income and expenses should be used cautiously as a benchmark for city data.

- A retrofit that costs the same in two similar buildings within two different communities could increase a building's value by $\$ 335,000$ in one neighborhood and by only $\$ 12,000$ in the other neighborhood.

- The capitalization rates for a neighborhood are one of the most important factors in whether an energy-efficiency retrofit is feasible for building owners.

- Refinancing presents a significant opportunity for building owners to realize the value of the energy-efficiency improvements and for programs to increase building owner participation. 


\section{Introduction}

Building science research conducted over the past few decades has proven that energy-efficiency measures decrease energy consumption in residential buildings. Eighteen percent of the existing housing units in the United States are in multifamily buildings (five or more units) (ACS 2013); this group presents unique challenges and factors. For example, one of the greatest strengths of the multifamily building sector can also be a limitation: In a residential building, a single retrofit can benefit hundreds of tenants; however, this may also discourage a building owner from investing in energy-efficiency measures, because the construction could disrupt tenants' lives. Building America and others are committed to understanding the energy savings potential in the multifamily sector (Choi, Ludwig, and Brand 2012).

Further, multifamily building stock is extremely varied. Building age, number of units, energy consumption, fuel type and delivery, and heating and cooling systems all vary with regional geography. However, when quantifying the financial benefits, a more granular geographic analysis is needed due to micromarkets in real estate. For instance, two similar buildings in Chicago may have comparable building characteristics and energy use, but rental income and market value vary with location. This diversity creates additional barriers when energyefficiency programs are implemented at scale.

Despite this, a focus on multifamily energy efficiency has substantial advantages. The unsubsidized affordable multifamily rental housing stock comprises a significant fraction of the affordable housing market across the nation (HUD 2013). Targeting affordable multifamily housing also provides additional financial benefits for building owners who are often working in rent-stagnant environments. For this project, affordable housing is defined as the unsubsidized units that have naturally occurring market rents in low-income neighborhoods.

Reports estimate an untapped $\$ 16$ billion energy cost savings in multifamily housing retrofits nationwide (ACEEE 2012). In addition, the positive consequences of energy efficiency outside of energy savings include the potential to create jobs (Bell 2012) and save families hundreds of millions of dollars per year on energy bills. Multifamily retrofits, when done properly, also help preserve affordable housing and result in safer, more comfortable homes for tenants.

In this project, the U.S. Department of Energy's Building America Research team Partnership for Advanced Residential Retrofit (PARR) focused on yet another positive impact of multifamily energy efficiency measures - the financial benefits it brings to building owners and investors.

To increase the adoption of multifamily energy-efficiency measures, which are necessary to realize the aforementioned benefits, the energy sector must understand and include qualified lenders and appraisers in the program process, because these stakeholders act as gatekeepers to capital and have a strong knowledge of real estate conditions. To date, the unique needs and requirements of these industries have not always been included in this process, especially when these programs rely heavily on utility rebates and government subsidies. Exploring the effect of energy efficiency on the financial performance of buildings is important because it integrates these currently disparate energy, lending, and appraisal sectors. 
Others agree that these financial benefits are important, including those in the private sector. Already, members from the lending and appraisal fields recognize that quantifying these benefits (Deutsche Bank 2012) is vital to decreasing energy consumption in buildings and fairly valuing improvements. The U.S. Department of Energy-sponsored State and Local Energy Efficiency Action Network Financing Solutions Working Group provides cross-industry participation. The Appraisal Institute offers multiple courses on how to appraise buildings with green features and has recently released a multifamily-specific green addendum that can be attached to a general appraisal (Appraisal Institute 2015). Efforts are being made to demonstrate that energy efficiency can improve the bottom line for businesses that own and manage multifamily buildings by reducing their energy bills, lowering maintenance and equipment costs, and lowering tenant turnover rates.

Historically, bringing these lending and appraisal industries into the energy-efficiency life cycle has presented challenges. Lenders tend to prefer predictable energy savings that come from consistently structured deals, but a recent State and Local Energy Efficiency Action Network paper notes, in reference to an energy-efficiency secondary market that, "as basic data needed to assess the risk and performance characteristics of energy efficiency loans accumulates, investor and program administrators' perspectives may come more into alignment" (SEE Action 2015). Further, a building's appraisal is based on the comparison of comparable buildings in close geographic proximity, which can be a challenge given the inherent diversity of the multifamily building stock and the improvements that are made.

The positive impact of energy efficiency on financial indicators (such as net operating income and market value) has been demonstrated in other sectors such as non-multifamily commercial buildings. This project attempts to provide more data about how these same indicators impact the multifamily market by exploring if, and to what extent, a building owner benefits financially from energy-efficiency improvements.

This project takes a three-pronged approach to analyzing the financial benefits of energy efficiency in multifamily buildings:

- Task 1 is a pre- and post-retrofit characterization. It looks at the building, energy, and financial characteristics of a subset of 13 Chicago multifamily buildings that were improved through Elevate Energy's buildings program. This task establishes the savings impacts and potential benefits for these multifamily building owners and resulted in key findings that could encourage owners to invest in energy efficiency. The buildings in this task will be referred to as "Task 1" buildings, or the "sample."

But to advance energy efficiency market penetration, we must understand how this local Chicago market compares to national samples.

- Task 2 is a comparison of Chicago multifamily building stock to two national financial data sets. This task shows that utility costs comprise a significant yet controllable expense for building owners. This reinforces the value of energy efficiency for owners and for the lenders and appraisers who can take this controllability into account when determining investment risk and building value. The sample of buildings used to represent Chicago will be referred to as the "Chicago data set." 
However, because multifamily building stock is varied down to the community level, the sector must better understand how location affects this valuation within the market.

- Task 3 is a local analysis of nine communities in the Chicago area and is accomplished by merging public and private data. Due to the city's volume of building stock and the wide variation in economic and real estate conditions within these communities, Chicago is an excellent environment in which to explore the effects of energy efficiency on buildings' financial performance.
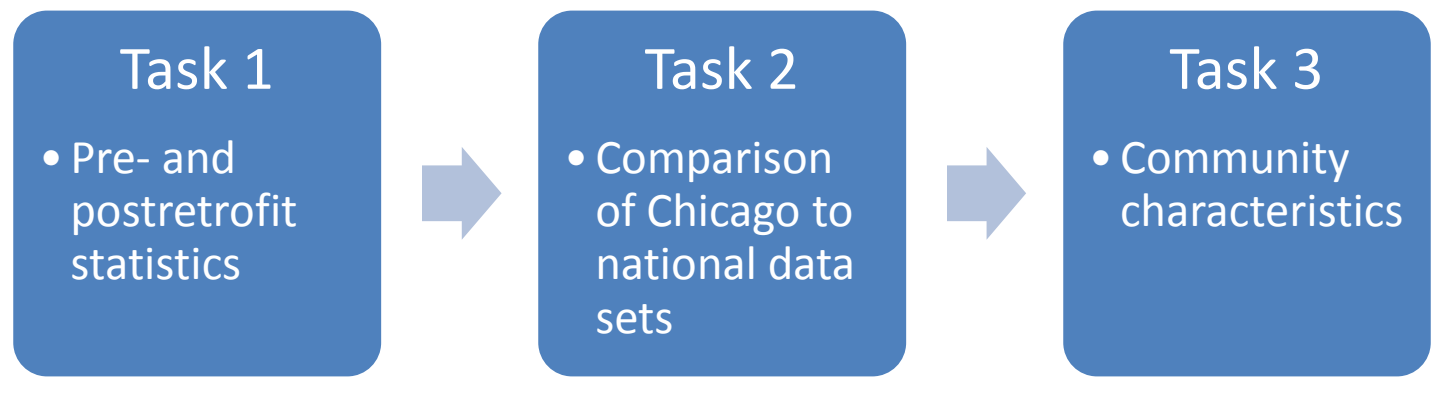

Taken together, these three tasks confirm a financial benefit to multifamily energy-efficiency improvements. They also highlight a key limitation that these financial benefits might not be realized without a combined effort from the energy, lending and appraising industries. This project works to mitigate this limitation by creating a replicable methodology for other local communities. This analysis needs to be completed in other geographies, and especially other climates, to understand how these findings vary across the United States' multifamily building stock.

This project supports Building America's commitment to decrease existing residential building energy consumption by $30 \%$ by 2020 as well as the goal to ensure that energy-efficiency investments are fairly valued at transaction points. This project is also relevant to U.S. Department of Energy data standardization and cross-industry data transfer initiatives such as Building Energy Data Exchange Specification and Better Buildings accelerators. 


\section{Pre- and Post-Retrofit Characterization (Task 1)}

Task 1 provided pre- and post-retrofit descriptive statistics of the income and expense, building, and energy characteristics of 13 multifamily buildings in Chicago that received energy-efficiency improvements through Elevate Energy's buildings program (Figure 1). Multifamily housing stock is an integral part of the Chicago landscape; more than 480,000 of the total 1.2 million housing units are in multifamily buildings with five or more units. Since 2008, Elevate Energy's buildings program has retrofitted more than 21,000 primarily rental, multifamily units in Illinois. The program provides a streamlined process in which the building owner receives an energy audit from an Elevate Energy analyst. The analyst manages the entire energy-efficiency process from contractor bidding through construction to a post-retrofit analysis. Merging this trio of data types - building, energy, and financial - is essential to demonstrating the effect of energyefficiency investment to sectors that all have unique motivations. Community Investment Corporation (CIC), which provides cost-effective financing for energy-efficiency improvements to buildings, provided the income and expense data and holds the first mortgages on all the buildings in the study. Another criterion for this sample is that the buildings all had at least one major heating, ventilating, and air-conditioning or envelope measure completed. The Elevate Energy buildings program does not require that any of the suggested measures be implemented, so retrofits often vary from project to project. 


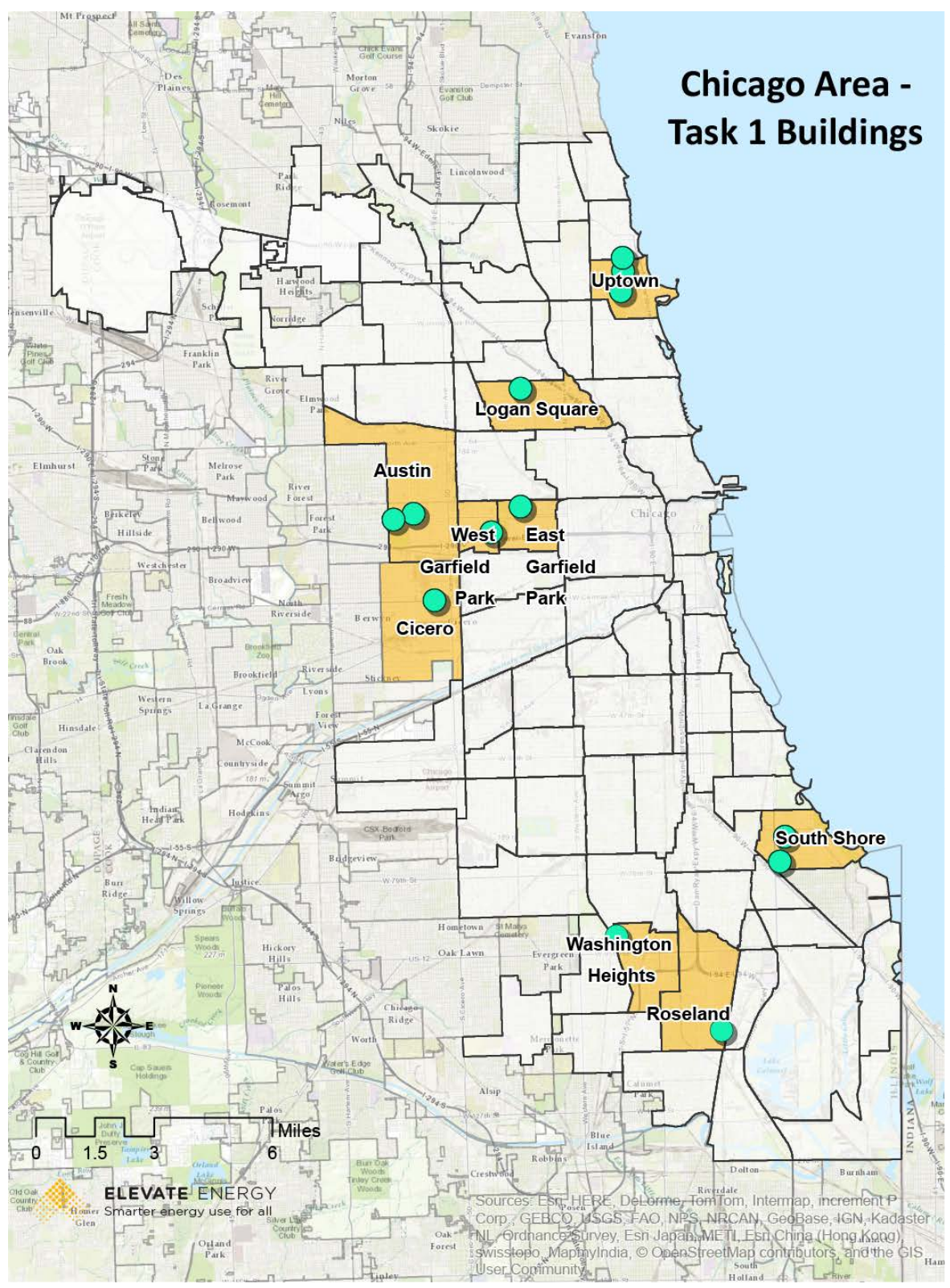

Figure 1. Locations of Task 1 buildings and corresponding communities

In brief, these buildings are small in size and operating budget and their age makes them good candidates for energy savings. Nearly all the energy-efficiency measures installed focus on decreasing natural gas therm use, because Chicago is in a cold climate that relies primarily on natural gas for space heating.

\subsection{Building Characteristics}

The 13 buildings in this sample are brick, three-story walk-ups that are typical in Chicago. They are often in a $\mathrm{U}$ or block shape with a courtyard and are representative examples of the Chicago multifamily rental housing stock (Figure 2). The majority of the buildings in this study are master-metered. 


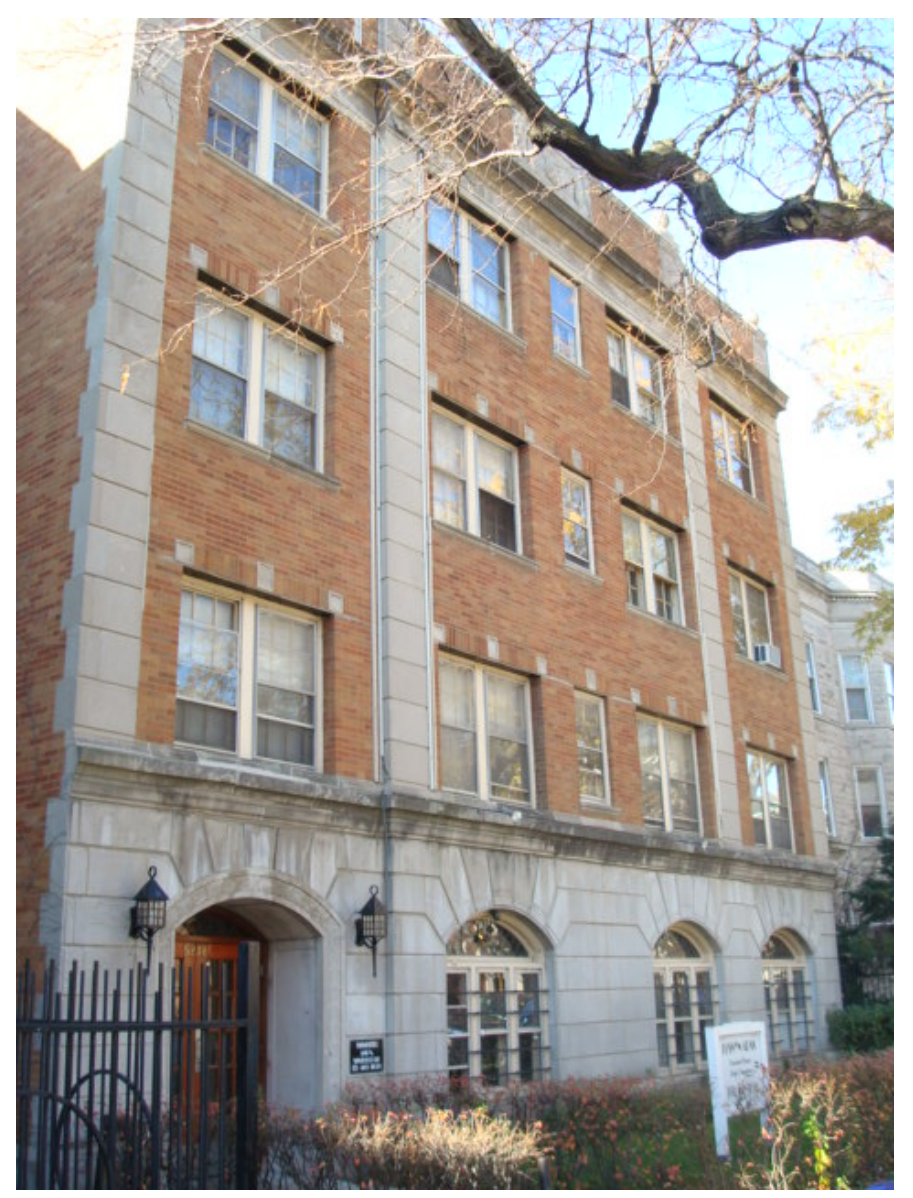

Figure 2. Example of a Chicago multifamily building Source: Elevate Energy

The buildings had a median built age of 95 years. They were built around 1920, long before modern energy codes. Most were master-metered and had a median of 30 units (Table 1). 
Table 1. Descriptive Building Characteristic Statistics

\begin{tabular}{c|c|c|c|c|c|c}
\hline Building & $\begin{array}{c}\text { Year } \\
\text { Built }\end{array}$ & Units & $\begin{array}{c}\text { Master- } \\
\text { Metered }\end{array}$ & $\begin{array}{c}\text { Conditioned } \\
\text { Square Feet }\end{array}$ & $\begin{array}{c}\text { Construction } \\
\text { Type }\end{array}$ & Community \\
\hline Median & 1920 & 30 & $92 \%$ & 21,372 & Brick & - \\
$\mathbf{1}$ & 1917 & 12 & Yes & 13,200 & Brick & Roseland \\
$\mathbf{2}$ & 1920 & 220 & Yes & 30,580 & Brick & Uptown \\
$\mathbf{3}$ & 1920 & 19 & Yes & 20,250 & Brick & Austin \\
$\mathbf{4}$ & 1920 & 30 & Yes & 23,800 & Brick & South Shore \\
$\mathbf{5}$ & 1929 & 6 & Yes & 6,650 & Brick & Cicero \\
$\mathbf{6}$ & 1921 & 73 & Yes & 36,680 & Brick & West Garfield Park \\
\hline $\mathbf{7}$ & 1926 & 51 & Yes & 42,230 & Brick & Logan Square \\
$\mathbf{8}$ & 1918 & 7 & No & 9,600 & Brick & East Garfield Park \\
\hline $\mathbf{9}$ & 1934 & 100 & Yes & 44,428 & Brick & Uptown \\
$\mathbf{1 0}$ & 1929 & 88 & Yes & 21,372 & Brick & Uptown \\
\hline $\mathbf{1 1}$ & 1920 & 12 & Yes & 16,854 & Brick & Austin \\
\hline $\mathbf{1 2}$ & 1920 & 13 & Yes & 12,324 & Brick & South Shore \\
\hline $\mathbf{1 3}$ & 1927 & 31 & Yes & 30,464 & Brick & Washington Heights \\
\hline
\end{tabular}

\subsection{Energy Use Characteristics}

The buildings in this sample are typical of Chicago multifamily buildings in that the majority of their energy use is natural gas for space heating. In fact, multifamily buildings in the Elevate Energy portfolio use substantially more natural gas (1.027 therms $/ \mathrm{ft}^{2}$, weather normalized $)$ than the multifamily buildings surveyed by Fannie Mae to develop the ENERGY STAR ${ }^{\circledR}$ Score for Multifamily buildings $\left(0.23\right.$ therms $\left./ \mathrm{ft}^{2}\right)$ (Fannie Mae 2014).

\subsection{Income and Expense Characteristics}

Income and expense data were provided by CIC, a Chicago-based Community Development Financial Institution. CIC requires that all building owners self-report these data for all buildings for which they hold the first mortgage. The median total expenses for these buildings were $\$ 99,766$, and the average retrofit cost was $\$ 59,247$. Table 2 outlines the data fields provided by CIC. The pre-upgrade data were from a median of 11 months before construction (2009) and at least 6 months and a heating season after the upgrade was finished (2012). The PARR team had to augment a few data fields to calculate the average post-retrofit percent saved and per-unit change. On eight occasions expenses either pre- or post-retrofit appeared to reflect an accounting error or an anomaly year. For example, the average percent of total expenses for repair costs might be $25 \%$, but for one building it appeared to be $70 \%$. For these extreme cases, the PARR team multiplied the building's total expenses by the average percentage of total expenses across all buildings for a given category. For example, if all buildings' post-retrofit management costs were $15 \%$ of their total expenses, the PARR team replaced the extreme value with $15 \%$ of that building's expenses. This allowed for a more even comparison of a small data set and replaced the outlier values with one more proportionally representative of the sample. 
Table 2. Income and Expense Variables

\begin{tabular}{|c|c}
\hline $\begin{array}{c}\text { Variable Name } \\
\text { Net Operating Income } \\
\text { (NOI) }\end{array}$ & Description \\
\hline Income \\
Rent \\
Expenses \\
Gas & Total income minus total expenses \\
\hline Electricity & Income produced by unit rentals \\
\hline Water and Sewer & Cost for owner-paid natural gas (weather normalized) \\
Management & Cost for owner-paid electricity in common spaces \\
Real Estate Tax & Cost for water and sewer \\
\hline Janitor & Cost for property manager or management company \\
Repairs & Cost of real estate tax \\
\hline Insurance & Cost of janitor \\
\hline Exterminator & Operations and maintenance costs \\
Security & Cost of building insurance \\
\hline Elevator & Cost of pest management \\
\hline Other Expenses & Cost of security system or personnel \\
\hline
\end{tabular}

The pre- and post-retrofit analyses revealed an encouraging picture of how energy-efficiency improvements impacted financial performance (Table 3). Results included the average decrease of almost $\$ 200 / \mathrm{ft}^{2}$ (more than $25 \%$ ) in natural gas expenditures. This was an expected outcome because the efficiency measures installed primarily targeted natural gas use. The savings related to natural gas are the equivalent of receiving nearly 2 months of additional rental income. This could prove particularly valuable if rent payments are late, or vacant units take an extra month to fill. Electricity costs increased $8.3 \%$, although they had very low cost per square foot. This is likely a product of the fluctuating cost of electricity, the small sample size, and data reporting error. The most encouraging change is a $2.95 \%$ average increase in NOI, or $\$ 55.96 /$ unit/year. 
Table 3. Pre-and Post-Retrofit Annual Income and Expenses, Mean of Reported Data from 13 Study Buildings ${ }^{12}$

\begin{tabular}{|c|c|c|c|c|}
\hline & $\begin{array}{c}\text { Pre- } \\
\text { Retrofit } \\
(\$ / \text { unit) }\end{array}$ & $\begin{array}{c}\text { Post- } \\
\text { Retrofit } \\
\text { (\$/unit) }\end{array}$ & $\begin{array}{c}\% \\
\text { Change }\end{array}$ & $\begin{array}{c}\$ / \text { Unit } \\
\text { Change }\end{array}$ \\
\cline { 2 - 5 } Mean & Mean & Mean & Mean \\
\hline Rental Income & $\$ 6,443.30$ & $\$ 6,654.53$ & $2.39 \%$ & $\$ 227.48$ \\
\hline Gas & $\$ 578.49$ & $\$ 393.82$ & $-26.14 \%$ & $\$(198.87)$ \\
\hline Electricity & $\$ 84.00$ & $\$ 84.05$ & $8.33 \%$ & $\$ 0.06$ \\
\hline Water & $\$ 153.42$ & $\$ 237.43$ & $43.94 \%$ & $\$ 90.47$ \\
\hline Management Fees & $\$ 145.12$ & $\$ 115.67$ & $501.54 \%$ & $\$(31.71)$ \\
\hline Real Estate Taxes & $\$ 642.24$ & $\$ 635.73$ & $9.18 \%$ & $\$(7.01)$ \\
\hline Operations and & $\$ 759.50$ & $\$ 840.82$ & $32.20 \%$ & $\$ 87.57$ \\
\hline Maintenance (repair) & $\$ 335.58$ & $\$ 328.39$ & $14.33 \%$ & $\$(7.75)$ \\
\hline Insurance & $\$ 103.16$ & $\$ 118.01$ & $71.60 \%$ & $\$ 15.99$ \\
\hline Pest Control & $\$ 33.56$ & $\$ 25.40$ & $\mathrm{~N} / \mathrm{A}$ & $\mathrm{N} / \mathrm{A}$ \\
\hline Elevator & $\$ 9.42$ & $\$ 11.56$ & $\mathrm{~N} / \mathrm{A}$ & $\mathrm{N} / \mathrm{A}$ \\
\hline Other Expenses & $\$ 154.25$ & $\$ 135.44$ & $5.46 \%$ & $\$(20.26)$ \\
\hline Total Expenses & $\$ 2,998.74$ & $\$ 2,926.31$ & $-2.33 \%$ & $\$(78.00)$ \\
\hline NOI & $\$ 3,706.0$ & $\$ 3,757.97$ & $2.95 \%$ & $\$ 55.96$ \\
\hline
\end{tabular}

Repair costs increased by $32 \%$, or $\$ 87 /$ unit. A possible explanation is that an increase in occupancy caused a spike in repairs. Because occupancy data were not available, the PARR team could not test this theory. The increase might also have been the result of a building owner reporting a capital expense such as installation of new appliances under "repairs," which should include only true repair items such as repainting. Interviews with buildings owners in previous research suggest that this is very likely (Elevate Energy 2014) and especially true of deferred maintenance. Another potential cause of the increased repair costs was that an investment in energy-efficiency upgrades might have motivated owners to continue making building upgrades in the immediate years after construction was complete.

Self-reported data presented obvious concerns. A $\$ 0$ on some of the variables shows that some building owners simply did not record particular expenses. PARR recognizes the limitations of self-reported data and the small sample size, and another cohort of similar buildings could likely produce different results. Furthermore, these results are not statistically significant. However, key findings might still encourage building owners to invest in energy-efficiency retrofits.

\subsection{Key Findings}

The net operating income of buildings that had energy-efficiency improvements increased by $2.95 \%$, or $\$ 55.96 /$ unit, 1 year post-improvement. NOI is a key indicator of a building's

\footnotetext{
${ }^{1}$ Because the "percentage change" and "dollars per unit change" are both independently calculated averages, the sign is sometimes different. This happens when the average is being driven by buildings that have a high percent change, but low true value change. For these expense categories, data often were not reported on all 13 buildings.

${ }^{2}$ The data here were self-reported from the building owner to the lender.
} 
health, because it denotes the ability the pay the debt service and serves as a benchmark for when building owners need to manage expenses more closely.

Following the energy-efficiency improvements, gas costs decreased by $26 \%$ and gas consumption decreased by $17 \%$ for post-improvement buildings. This confirms that substantial reduction in consumption is possible through improvements that cost less than $\$ 100,000$.

\section{Rental incomes increased by more than $\$ 225$ /unit annually in the year after energy-}

efficiency improvements were completed. Occupancy and turnover cost data were lacking, so the PARR team could not be certain about whether rental income increased due to higher rents or a lower vacancy rate, potentially coupled with decreased turnover. Regardless, higher revenues allowed building owners to weather unexpected expenses and volatile energy prices and to pay into their capital reserves.

Demonstrating a financial benefit for the owners of this group of buildings is noteworthy, but to advance the market penetration of energy-efficiency improvements, the PARR team explored how the buildings' locations within a particular community are tied to and affect the realization of financial benefits. 


\section{Comparison of the Chicago Buildings to National Financial Data Sets (Task 2)}

Task 2 compared the income and expenses of Chicago multifamily buildings to two nationally representative surveys, the Rental Housing Financial Survey (RHFS) and the National Apartment Association's (NAA's) Survey of Operating Income and Expenses in Rental Apartment Communities. It is important to know how a local market compares to national samples so policymakers and advocates can judge the appropriateness of using national data as a benchmark.

\subsection{Data Sets}

This section explores the data used in three data sets provided by CIC, RHFS, and NAA.

\subsubsection{Chicago Data Set}

The income and expense data set for the Chicago sample is from the 2013 financial reporting of Elevate Energy's lending partner, CIC. The original data set was 368 buildings, but t-tests showed that the difference in the mean for the "other expenses" categories was statistically significant ( $p$-value $=0.028$ ) at a $95 \%$ confidence level for buildings that received energy audits and those that did not. Buildings that had received an audit might have been categorizing upgrades in the "other" category, which raised concerns. Therefore, the PARR team included only buildings that had a complete audit, which provided the benefit of a data set that was as representative as possible to the buildings in Chicago that were likely to be improved through Elevate Energy's building program.

Of the 110 buildings remaining in the data set, 43 had completed energy-efficiency improvements through Elevate Energy. All buildings have first mortgages with CIC and rental income, and expense data were self-reported by building owners.

\subsubsection{U.S. Department of Housing and Urban Development's Rental Housing Finance Survey}

RHFS was commissioned by the U.S. Department of Housing and Urban Development and administered by the U.S. Census Bureau in 2012. Its purpose is to "provide current and continuous measure of financial, mortgage and property characteristics of multifamily rental housing properties in the United States" (HUD 2013). Data collected include information about the purchase, refinancing, and loan terms associated with properties as well as number of units, income and expense data, and included amenities. The RHFS data set includes 1,195 properties. The vast majority of the buildings $(70 \%)$ had only two to four units and the median year of construction for all units was 1951 . This survey has been administered only once.

The data are collected for use by policymakers to develop multifamily housing practices that pertain to financing deals that will benefit low-income families. An alternative use stated by the U.S. Department of Housing and Urban Development is for private enterprises involved in housing development, ownership, and management to benchmark financial data. Because of these stated intentions, individual markets must determine if the nationally representative sample is congruent with local data. 


\subsubsection{The National Apartment Association's Survey of Operating Income and Expenses (2013)}

The National Apartment Association's Survey of Operating Income and Expenses is an annual survey that collects operating data about a nationally representative sample of multifamily buildings.

The survey presents data from 4,526 properties and 1,138,056 units. Data were reported for 4,117 market rental properties that contained 1,077,468 units and 409 subsidized properties that contained 60,588 units. Because the survey is longitudinal (2013 was the 25th year), NAA can report changes in the market that are of interest to its membership, which consists of building owners, management companies, developers, investors, and other related multifamily stakeholders. Although the survey does not have a stated purpose, the organization has "a joint legislative alliance with the National Multi Housing Council, NAA protects and represents our members' interests with regard to legislative and regulatory issues at the federal government level" (NAA 2015).

\subsection{Attributes of the Data Sets}

Buildings in the Chicago data set had a median of 16.5 units, $66 \%$ of which were mastermetered. As seen in Figure 3, the category "other" is the largest expense (\$968/unit annually). This category is a catch-all for marketing, personnel, and other costs. Unfortunately, line items in this category are separated out in the NAA data set but not in the Chicago data set; this omission prevents additional comparisons. Another notable expense in the Chicago data set includes the significant gas costs (\$698/unit), which, when combined with electricity and water, makes utilities the most expensive part of the building's operating expenses.

\section{Chicago Annual Expenses per Unit (2013)}

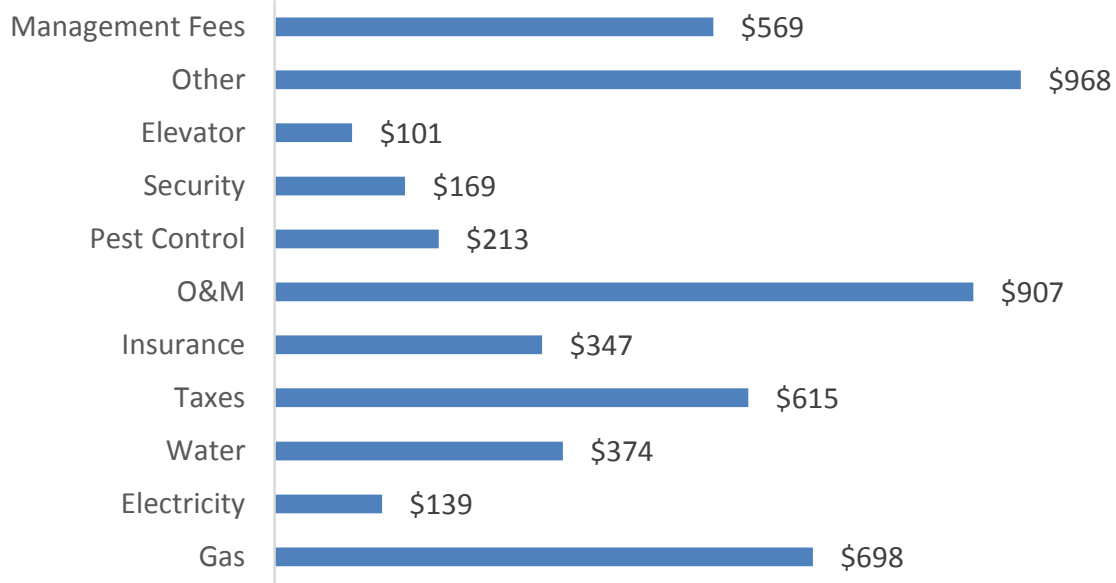

Figure 3. Annual expenses per unit for Chicago data set 
For most of the comparison between Chicago and the national data sets, the PARR team used all 110 Chicago buildings. ${ }^{3}$ However, for the comparison of capital funds spent, only the 43 buildings that underwent retrofits are included. This is because capital expenses are not included in the data set from CIC, but Elevate Energy has a record of the amount spent on the improvements.

The national data sets and the Chicago data have other key differences. To increase comparability, the PARR team used data from the RHFS for buildings that had fewer than 25 units. The properties are a mix of subsidized, master-metered, and individually metered buildings. The NAA data included buildings that were unsubsidized, master-metered, and garden level (five or fewer stories). Despite the height restrictions, they still had a large number of units (the mean was 244).

\subsection{Key Findings}

Utility costs per unit are twice the property taxes in Chicago. Although the income and expenses of Chicago buildings hold some similarities with both national data sets, key differences emerge (Figure 4). For one, Chicago property taxes are significantly lower than other metropolitan areas. In an urban property tax study, Chicago ranked 26 out of 53 urban centers (Lincoln Institute of Land Policy 2011). The comparatively low property taxes in Chicago illustrate that owners have a larger percentage of their operating costs in a category (utilities) that they can reduce, which can positively impact their bottom lines. In the NAA survey, utilities are still higher than the property taxes, but only by $\$ 170$ annually.

\section{Income and Expense Data (per Unit)}

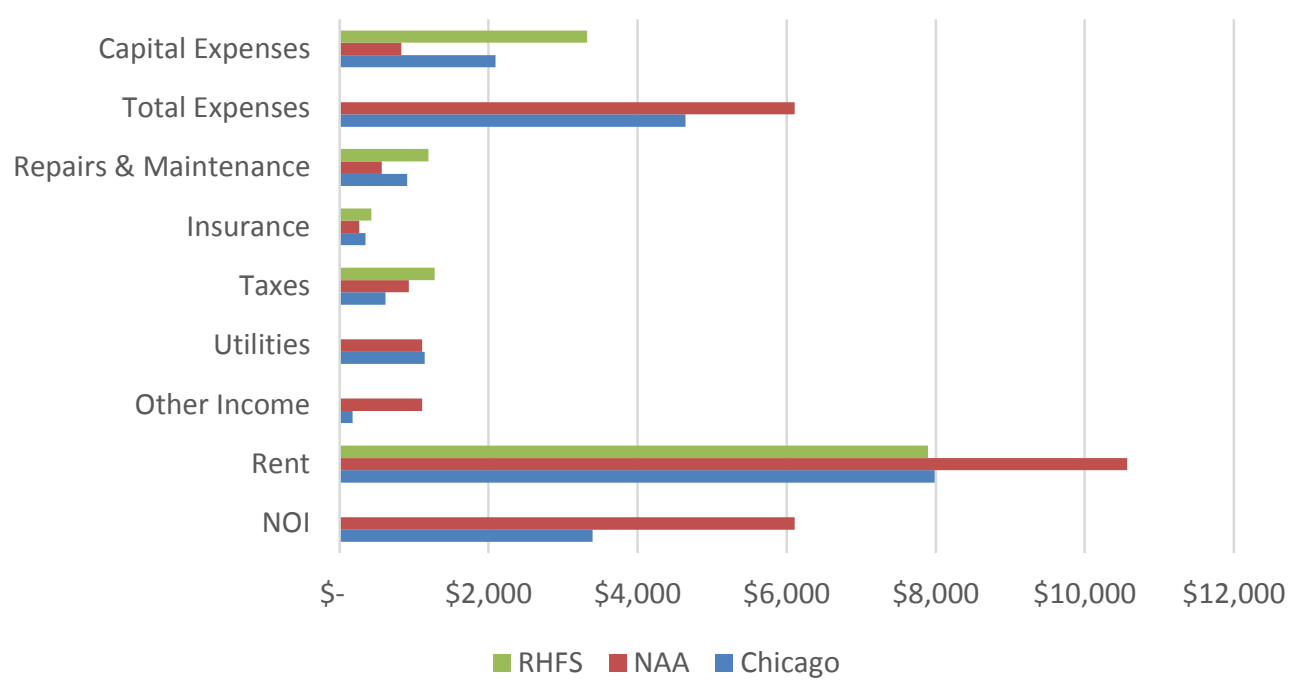

Figure 4. Income and expense variables by survey

\footnotetext{
${ }^{3}$ Due to the reporting categories of the Chicago buildings, comparisons were not made for each variable across the three data sets.
} 
Utility costs are one of the largest building operating expenses in Chicago and nationally. The comparison of the Chicago financial data set to the national financial data set shows that utility costs in Chicago and nationally are one of the highest costs for building owners and exceed taxes and insurance. This trend further reinforces the value of reducing energy costs to increase NOI. The fact that utility costs - a large, variable expense - are higher than other costs (including taxes and insurance) and are controllable reinforces the importance of reduced energy costs and the value of energy-efficiency improvements to an owner's bottom line. Lenders and appraisers should absolutely consider the ability to influence energy costs as they determine the level of risk an investment poses and the building's value.

The capital expenses in Chicago are more closely aligned with those in the RHFS than those in the NAA (Table 4). However, the Chicago capital expense per unit is likely lower than shown, because the PARR team used the retrofit cost per unit as a proxy for owner-reported data. Not all measures in a retrofit, such as replacing boiler controls, should be categorized as capital expenses, but most high-cost items such as furnace replacement and roof cavity insulation are traditionally considered capital expenses. Previous research (Elevate Energy 2014) suggests that deferred in-unit expenses such as equipment replacement can be categorized as repairs and maintenance costs instead of as capital expenses.

Table 4. Annual Financial Indicators per Unit for Each Data Set

\begin{tabular}{|c|c|c|c|c|c|c|c|c|c|c|}
\hline & $\overline{\mathbf{o}}$ & $\underset{\mathscr{E}}{\breve{\Xi}}$ & 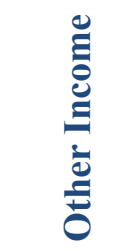 & & 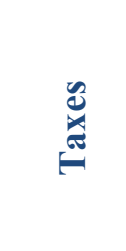 & 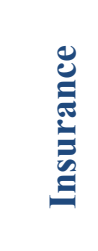 & 䒕 & 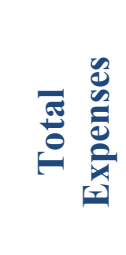 & 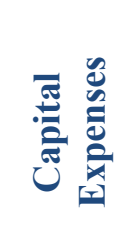 & 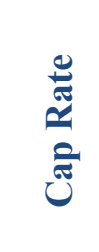 \\
\hline Chicago & $\$ 3,398$ & $\$ 7,985$ & $\$ 177$ & $\$ 1,145$ & $\$ 615$ & $\$ 347$ & $\$ 907$ & $\$ 4,643$ & $\$ 2,094$ & $8.4 \%$ \\
\hline NAA & $\$ 6,105$ & $\$ 10,570$ & $\$ 1,108$ & $\$ 1,108$ & $\$ 932$ & $\$ 263$ & $\$ 567$ & $\$ 6,105$ & $\$ 830$ & - \\
\hline RHFS & - & $\$ 7,896$ & - & - & $\$ 1,278$ & $\$ 428$ & $\$ 1,192$ & - & $\$ 3,324$ & $5.9 \%$ \\
\hline
\end{tabular}

Sources: RHFS (2012), NAA (2013), CoStar (2014)

National data sets of income and expenses should be used cautiously as a benchmark for

Chicago data. The Chicago data set was comparable to only one of the two national data sets for a given variable. This has serious implications if policymakers and housing advocates expect Chicago to perform similarly. The gap in NOI between Chicago and the NAA and the capitalization (cap) rate, the ratio of NOI to property value, between Chicago and the RHFS are especially important. As will be discussed shortly, these two indicators greatly influence a buildings' market value and performance expectations by lenders. 


\section{Characteristics of Community Areas (Task 3)}

Task 3 analyzed relevant financial, housing, and building characteristics of the nine communities in which the Task 1 buildings were located to better understand how location affects the valuation of energy-efficiency improvements on a building's market value. The PARR team aggregated public data to uncover areas of opportunities and lessons learned from Chicago neighborhoods that can be applied in other geographies.

This project focused on the nine communities where the Task 1 buildings were located (Table 5). These neighborhoods are also home to a large number of the buildings that Elevate Energy's buildings program operates (see the Appendix). Chicago is located in Cook County, which is home to 750,000 multifamily units, more than 210,000 of which are unsubsidized affordable housing units.

\begin{tabular}{c} 
Table 5. Chicago Area Communities in This \\
$\qquad \begin{array}{c}\text { Communities } \\
\text { Uptown } \\
\text { Logan Square } \\
\text { Austin } \\
\text { West Garfield Park } \\
\text { East Garfield Park } \\
\text { South Shore } \\
\text { Washington Heights } \\
\text { Roseland } \\
\text { Cicero }\end{array}$ \\
\hline
\end{tabular}

\subsection{Data}

To characterize the community areas, the PARR team collected data from a variety of sources including CoStar Groups, the Home Mortgage Disclosure Act, and Elevate Energy's affordability data set, which has inputs from the American Community Survey, the National Housing Preservation Database, and the New Markets Tax Credit database.

\subsubsection{CoStar}

CoStar Group offers a commercial real estate database that gathers data from more than 500,000 brokers, owners, lenders, investors, asset managers, appraisers, and others. It has the largest and most comprehensive database of multifamily properties in the United States. Despite its large depository of buildings, limitations arise in low-income neighborhoods where buildings have a lower market value and relatively few transactions. The CoStar can be searched for individual buildings listed and viewed for aggregate sales statistics from the previous 12 months. For each community area, the PARR team could record the sales volume, number of properties sold, average sales price, average price per unit, and cap rate.

\subsubsection{Home Mortgage Disclosure Act}

The Home Mortgage Disclosure Act requires that certain lending institutions report details of mortgages such as the type of loan, loan size, and census tract for the property. The PARR team compiled the loan types for each community area. 


\subsubsection{Elevate Energy Multifamily Affordability Data Set}

Elevate Energy has analyzed data from the American Community Survey, the National Housing Preservation Database, and the New Market Tax Credit Database at the census tract level. Data points calculated included the number of market rate and affordable units, further broken down into naturally occurring affordable, subsidized, and public housing authority units. These data were then amassed from the census tract level to the community area.

\subsection{Trends in Housing Stock and Sales Data}

The Sections 4.2.1 through 4.2.3 discuss the trends in housing stock, sales, and mortgage data in each community.

\subsubsection{Multifamily Housing Stock}

Multifamily housing stock is an integral part of the Chicago landscape; more than half the renters reside in multifamily buildings with five or more units. Of the communities included in the study, Uptown and Austin have the largest multifamily markets (26,617 and 12,714 multifamily units, respectively) (Table 6). Although almost all units are affordable (due to household incomes and the rents that those buildings can demand), some areas have more unsubsidized stock than others. Unsubsidized affordable units are important because they are representative of the buildings in Task 1, and because adoption of energy efficiency in this segment of the market will signal a milestone in market penetration. Later in this report, the financial barriers to investing in energy efficiency will be discussed.

Table 6. Multifamily Housing Stock

\begin{tabular}{c|c|c|c}
\hline Community & $\begin{array}{c}\text { Total } \\
\text { Multifamily } \\
\text { Units }\end{array}$ & $\begin{array}{c}\text { Total } \\
\text { Affordable } \\
\text { Units }\end{array}$ & $\begin{array}{c}\text { Percent } \\
\text { Unsubsidized } \\
\text { Affordable }\end{array}$ \\
\hline Uptown & 26,617 & 18,890 & $72 \%$ \\
\hline Logan Square & 7,068 & 5,203 & $75 \%$ \\
Austin & 12,714 & 5,960 & $46 \%$ \\
West Garfield Park & 3,710 & 2,451 & $65 \%$ \\
East Garfield Park & 6,395 & 6,395 & $51 \%$ \\
\hline South Shore & 3,256 & 3,048 & $53 \%$ \\
\hline Washington Heights & 4,264 & 1,971 & $90 \%$ \\
\hline Roseland & 1,034 & 1,034 & $100 \%$ \\
\hline Cicero & 3,987 & 3,270 & $75 \%$ \\
Chicago & 482,514 & 251,116 & $57 \%$ \\
\hline
\end{tabular}

Source: Elevate Energy analysis with inputs from ACS 2013 5-year estimates, NHPD, NMTC database

A neighborhood such as Austin has a strong concentration of affordable multifamily buildings; however, a smaller percentage of those are unsubsidized compared to other communities (Figure $5)$. 


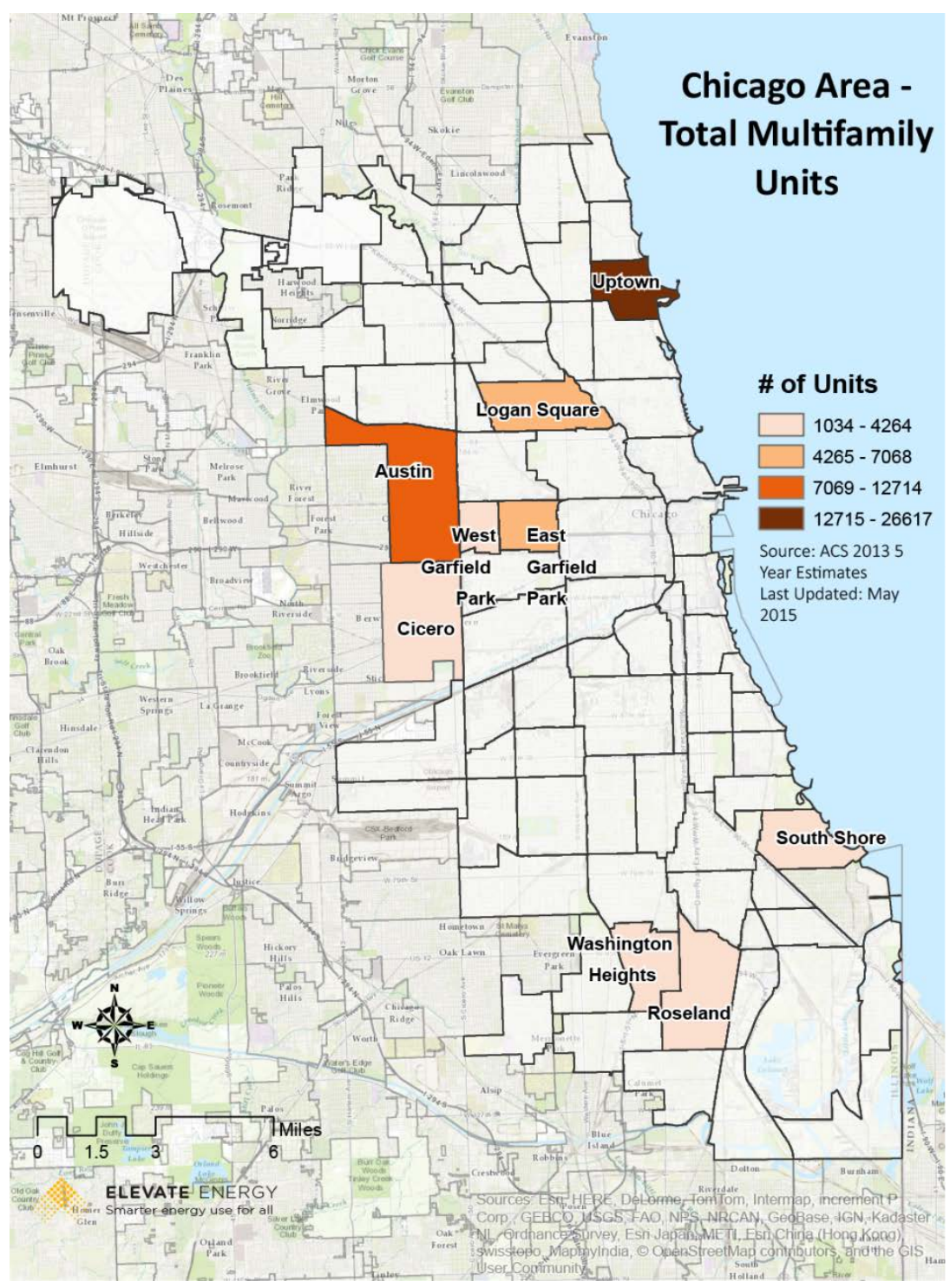

Figure 5. Total multifamily units

\subsubsection{Rent and Sales Data}

The rent and sales metrics (Table 7) for multifamily buildings in these communities over a recent 12-month period (March 2014 to February 2015) demonstrate the extreme variation in local markets even among neighborhoods that traditionally support low- and moderate-income families. Uptown and Logan Square are both experiencing an infusion of capital and intense gentrification. Their current attractiveness to investors is reflected in a sales price per unit rate that is three to five times that of other neighborhoods. Furthermore, the cap rate in these two communities is lower than the Chicago average, which indicates that investors are willing to move into the market. 
Table 7. Sales and Rent Data

\begin{tabular}{|c|c|c|c|c|c|c|}
\hline & 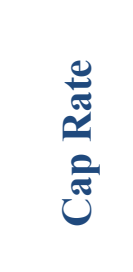 & 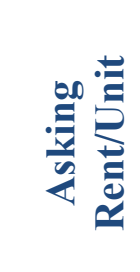 & 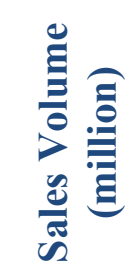 & 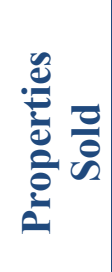 & 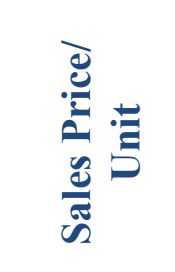 & 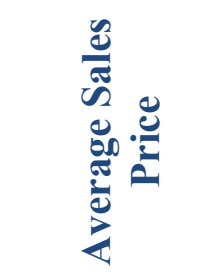 \\
\hline Uptown & $6.8 \%$ & $\$ 986$ & $\$ 14$ & 9 & $\$ 85,076$ & $\$ 1,607,000$ \\
\hline Logan Square & $7.3 \%$ & $\$ 980$ & $\$ 28$ & 16 & $\$ 101,229$ & $\$ 1,733,562$ \\
\hline Austin & $13.8 \%$ & $\$ 777$ & $\$ 6$ & 14 & $\$ 28,382$ & $\$ 405,464$ \\
\hline West Garfield Park & - & $\$ 942$ & $\$ 1$ & 2 & $\$ 16,014$ & $\$ 552,500$ \\
\hline East Garfield Park & - & $\$ 896$ & $\$ 1$ & 2 & $\$ 32,500$ & $\$ 292,500$ \\
\hline South Shore & $11.8 \%$ & $\$ 833$ & $\$ 22$ & 34 & $\$ 30,709$ & $\$ 650,317$ \\
\hline Washington Heights & - & $\$ 907$ & $\$ 0$ & 0 & - & - \\
\hline Roseland & - & $\$ 620$ & $\$ 0$ & 0 & - & - \\
\hline Cicero & $10.3 \%$ & $\$ 646$ & $\$ 2.2$ & 6 & $\$ 27,312$ & $\$ 364,166$ \\
\hline Chicago & $8.4 \%$ & $\$ 1,136$ & $\$ 2976$ & 711 & $\$ 120,861$ & $\$ 4,185,970$ \\
\hline
\end{tabular}

Source: CoStar Group, March 2014 to February 2015

South Shore has a complicated story. Though it has the highest total sales and number of properties sold from March 2013 to February 2014, the average sales price is one-third that of Logan Square. Section 4.3 explores how the significantly larger cap rate of South Shore (11.8\%) to Logan Square $(7.3 \%)$ perpetuates low market rates.

In communities where more than two properties sold, the capitalization rate was available. The cap rate is a real estate metric that indicates the estimated value of an investment. Cap rate, estimated market value, and annual net operating income are related in following equation:

\section{Annual NOI/Capitalization Rate = Market Value}

Cap rates are set by an appraiser and are generally informed by the recent sales of comparable buildings in similar locations. A lower cap rate is indicative of a less risky investment. For example, if a building were located in rural Illinois and an identical building were located in downtown Chicago, the one in Chicago would have a lower cap rate because recent sales data show that properties in that area are more valuable (Table 8). However, the likelihood of two identical buildings being able to produce identical net operating incomes is low. For instance, even if the operating expenses were the same, a building in rural Illinois cannot command the same rents as one in Chicago.

Table 8. Calculating NOI

\begin{tabular}{c|c|c}
\hline & Austin & Lincoln Park \\
\hline Cap Rate & $13.8 \%$ & $5.3 \%$ \\
Average Sales Price & $\$ 405,464$ & $\$ 11,357,666$ \\
NOI & $\$ 55,954$ & $\$ 601,956$ \\
\hline
\end{tabular}


The relationship between the cap rate, NOI, and market value figures seems simple, but upon further examination it reveals deep inequities across neighborhoods and subsequently presents barriers for multifamily buildings to realize the true value of investing in energy efficiency. The ramifications of this equation also impact a building owner's ability to access capital and reinvest in affordable housing.

To illustrate the control this relationship has over buildings' financial standings, two community areas are compared: Austin and Lincoln Park. Lincoln Park is an affluent neighborhood on the north side of Chicago. Austin's cap rate was 13.8\% during this time period; Lincoln Park's was 5.3\%. Lincoln Park experienced $\$ 68$ million in multifamily sales with an average sales price per property of $\$ 11,357,666$. The average sales price per unit was more than $\$ 235,000$. Austin's average sales price per property was $\$ 405,464$, and the price per unit was a little more than $\$ 28,000$. Using the equation above, the building in Austin has an annual NOI of $\$ 55,954$, and the building in Lincoln Park has an annual NOI of $\$ 601,956$.

The typical cost of energy-efficiency improvements to a multifamily building in Chicago through Elevate Energy's buildings program is $\$ 60,000$. An owner in Austin who wants to move forward with improvements must either access the funds through capital reserves or finance the upgrades. The building in Lincoln Park has more financing options.

\subsubsection{Housing Mortgage Disclosure Act Data}

The types of transactions in a market must be evaluated to increase adoption of and accurately evaluate energy-efficiency improvements. According to the 2013 Housing Mortgage Disclosure Act records, 56\% of mortgages issued were for refinancing (Figure 6). This is a signal to energy efficiency program administrators that buildings should be targeted at this time. It stresses the need to maintain close relationships with lenders to maintain a steady referral stream. Working with building owners during a refinance has advantages. A building owner already understands a specific building's expenses and likely has experience dealing with the complaints about aging equipment that can be addressed by energy-efficiency improvements. 


\section{Loan Type by Community}

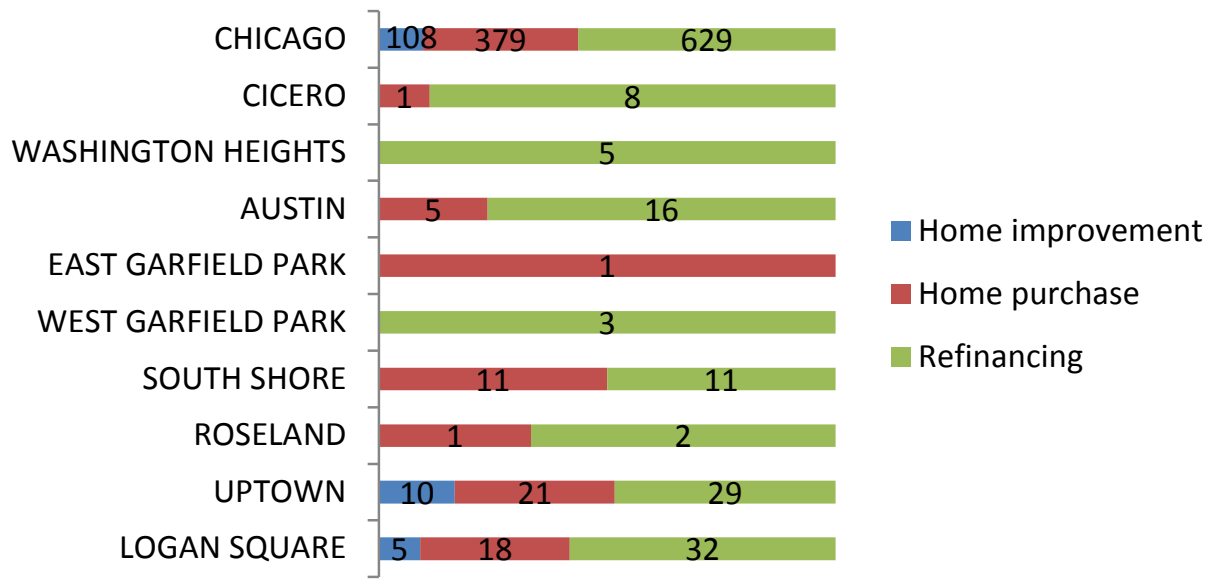

Figure 6. Loan type by community

Source: Consumer Financial Protection Bureau (2013)

The CoStar data showed a greater number of building purchases than did the Home Mortgage Disclosure Act. Only certain financial institutions are required to comply with the Home Mortgage Disclosure Act. Key players in the low and moderate-income lending space, such as CDFIs, are not required to comply. The volume of home purchase mortgages may not be a function of a lack of interest, but rather a lack of access to capital. A recent report by the Institute for Housing Studies at DePaul University found that in 2005, multifamily loans of less than \$1 million originated by small banks (those with less than $\$ 1$ billion in assets) in low- and moderate-income neighborhoods comprised almost 18\% of multifamily loan dollars in Cook County. However, from 2005 to 2013 the volume of these loans decreased by $72 \%$ (IHS 2014) as small banks went out of business and bigger banks refused to lend to what they perceived as riskier investments.

\subsection{Key Findings}

A retrofit that costs the same in two similar buildings within two communities could increase the buildings' values differently. Assuming that the $2.95 \%$ increase in NOI is realized in Lincoln Park as it was in the other community areas, the retrofit will increase the market value of that building by $\$ 335,000$. The building in Austin would see its value increase by only $\$ 12,000$. As mentioned earlier, the building in Lincoln Park had an NOI more than six times higher than that of a building in Austin. Although this substantial variance is a mathematical result of the relationship between cap rate, NOI, and market value, it nevertheless brings up meaningful and noteworthy inequities in terms of location and value.

The cap rates for a neighborhood are one of the most important factors in whether an energy-efficiency retrofit is feasible for building owners. As demonstrated in the above example of Austin and Lincoln Park, a high cap rate can suppress the value of a multifamily building. However, if stakeholders in the United States are going to take advantage the multifamily energy and cost savings potential, operating in areas with high cap rates is 
inevitable. The program implementers, lending, and appraisal professionals need to then structure deals in a way that are attractive to building owners and their businesses.

Refinancing presents a significant opportunity for building owners to realize the value of the energy-efficiency improvements and for programs to increase building owner participation. Fifty-six percent of multifamily mortgages in Chicago in 2013 were for refinancing. In the neighborhoods the PARR team analyzed, the percentage of refinances was even higher at $59 \%$. Even though this may be the result of low interest rates, energy efficiency programs and lending and appraisal professionals need to recognize this transaction point as an opportunity to work with building owners to ensure that completed improvements are fairly valued or, if they plan to make improvements later, that these future measures are also incorporated and fairly valued. 


\section{Conclusion}

In this study, the metrics show that multifamily building energy-efficiency upgrades can have a measurable financial benefit in existing buildings. Depending on rent changes as a consequence to the upgrade, the net operating income of the building can increase. In the Task 1 study, for example, the NOIs of buildings that had energy-efficiency upgrades increased by $2.95 \% 1$ year post-upgrade from utility cost reduction rent increases and other factors.

In the Task 2 study, the team concluded that the financial benefits of energy-efficiency upgrades for Chicago may not be the same as on a national level because though utility costs are one of the largest building operating expenses in Chicago and in the nation, relatively lower property taxes mean utility costs per unit are twice the property tax cost in Chicago. National data sets of income and expenses should be used cautiously as a benchmark for Chicago data - they can differ significantly. Furthermore, this task confirms that reducing utility costs is an effective way to decrease operating expenses.

In the Task 3 study, the team concluded that location can have a significant effect on the financial benefit metrics: a retrofit that costs the same could increase one multifamily building's value by $\$ 335,000$ and another by only $\$ 12,000$ in two neighborhoods. The retrofit pays for itself five times over in the building in the more affluent neighborhood. The cap rates for a neighborhood are one of the most important factors in whether or not an energy-efficiency retrofit is feasible for building owners. Finally, refinancing presents a substantial opportunity for building owners to realize the value of the energy-efficiency upgrades and for programs to increase building owner participation.

Overall, the low volume of sales, high cap rates, and below-market sales price per unit in underserved communities is a reminder of the barriers to lending and indicates the greater difficulty for building owners to see their investments fairly valued. A large volume of sales is important because it gives appraisers a variety of buildings to use as a benchmark, but appraisers should take care to lower the cap rate when appropriate because an increased NOI is attributed to energy-efficiency improvements. The cap rate definition above can be used to see how the cap rate would be lower for an Austin building, if NOI is assumed to increase by $2.95 \%$ and the market value increases by $50 \%$ of the cost of the improvements (Table 9).

Table 9. Example of Cap Rate Decreasing with Energy Efficiency

\begin{tabular}{|c|c|c|c|c|}
\hline Annual NOI & / & Cap Rate & $=$ & Market Value \\
\hline$\$ 55,954$ & 1 & $13.8 \%$ & $=$ & $\$ 405,464$ \\
\hline $\begin{array}{c}\$ 57,625 \\
(\mathrm{NOI}+\mathbf{2 . 9 5 \%})\end{array}$ & / & $13.2 \%$ & $=$ & $\begin{array}{c}\$ 435,464 \\
(\mathrm{MV}+\$ 30,000)\end{array}$ \\
\hline
\end{tabular}

The authors propose that lending practices should acknowledge the financial benefits of energy efficiency. Financial institutions typically use a range for loan-to-value and debt service coverage ratio. When a loan is perceived as exceptionally risky, the loan-to-value will be lower, 
which means that a building owner might not be offered the full amount requested. Lenders might also require a higher debt service coverage ratio, which is the ratio of income to money needed to support the mortgage. A higher debt service coverage ratio suggests that a lender is not confident in the consistency of a property's rental income.

This project confirms a potential financial benefit to improving the energy efficiency of multifamily buildings. However, it also highlights that these financial benefits might not be fully realized without a combined and collaborative effort from the energy, lending, and appraising industries. A close partnership is critical to make energy efficiency accessible in neighborhoods where traditional financing products create barriers for owners to invest in and improve their buildings.

Furthermore, the authors have demonstrated the ability to combine building, energy, and financial data from energy-efficiency programs as well as other public and private sources to analyze the effect of energy efficiency on multiple levels. Even though this methodology is replicable, it might produce very different results in another market. Also, because real estate and some financial variables, such as energy costs and taxes, can vary greatly over time, the findings in this project might be different if replicated 5 years from now. 


\section{References}

ACEEE. 2012. Appendix B: Details of States' Energy Efficiency Resource Standards in the 2012 State Energy Efficiency Scorecard, No. E12C. Washington, D.C.: American Council for an Energy-Efficient Economy.

American Community Survey. 2013. Table B25024: Units in Structure, 2009-2013 American Community Survey 5-Year Estimates. Accessed April 1, 2015: http://factfinder.census.gov/faces/tableservices/jsf/pages/productview.xhtml?pid=ACS_13_5YR B25024\&prodType $=$ table

Appraisal Institute. 2015. “Green Building Resources.” Accessed February 22, 2015: www.appraisalinstitute.org/education/education-resources/green-building-resources/.

Bell, C. 2012. Energy Efficiency Job Creation: Real World Experiences. ACEEE, Table A-1, 14, October 2012.

Choi, J., P. Ludwig, and L. Brand. 2012. Steam System Balancing and Tuning for Multifamily Residential Buildings in Chicagoland (Subcontract Report, NREL/SR-5500-60003. Golden, CO: National Renewable Energy Laboratory, www.nrel.gov/docs/fy13 osti/60003.pdf?gathStatIcon=true.

Deutsche Bank. 2012. The Benefits of Energy Efficiency in Multifamily Affordable Housing. Frankfurt am Main, Germany: Deutsche Bank.

Elevate Energy. 2014. Valuing the Financial Benefits of Energy Efficiency in the Multifamily Sector. Chicago, IL: Elevate Energy.

Fannie Mae. 2014. Transforming Multifamily Housing: Fannie Mae's Green Initiative and Energy Star ${ }^{\circledR}$ for Multifamily. Accessed December 1, 2014:

https://www.fanniemae.com/content/fact_sheet/energy-star-for-multifamily.pdf

Consumer Financial Protection Bureau. 2013. The Housing Mortgage Disclosure Act. Accessed May 31, 2015: http://www.consumerfinance.gov/hmda/

HUD. 2013. "Preserving Affordable Rental Housing: A Snapshot of Growing Need, Current Threats, and Innovative Solutions. Evidence Matters." U.S. Department of Housing and Urban Development. Accessed September 10, 2014:www.huduser.org/portal/periodicals/em/summer13/highlight1.html.

IHS. 2014. "The State of Rental Housing in Cook County: Understanding Neighborhood Multifamily Lending Trends in the Wake of the Housing Crisis." Institute of Housing Studies at DePaul University. Accessed October 1, 2015: www.housingstudies.org/researchpublications/state-of-housing/understanding-neighborhood-multifamily-lending-tre/. 
Lincoln Institute of Land Policy. 2011. 50-State Property Tax Comparison Study. Accessed April 1, 2015: www.lincolninst.edu/subcenters/significant-features-propertytax/upload/sources/ContentPages/documents/MTAdoc NewCover.pdf.

NAA. 2015. “About Us.” National Apartment Association. Accessed April 4, 2015: www.naahq.org/about.

RHFS. 2012. U.S. Department of Housing and Urban Development (2015). U.S. Rental Housing Finance Survey: About. Accessed 15 June 2014 at http://www.huduser.org/portal/datasets/rhfs/home.html.

SEE Action. 2015. Accessing Secondary Markets as a Capital Source for Energy Efficiency Finance Programs: Program Design Considerations for Policymakers and Administrators. Washington, D.C.: State and Local Energy Efficiency Action Network. 


\section{Appendix: Elevate Energy Multifamily Program Metrics}

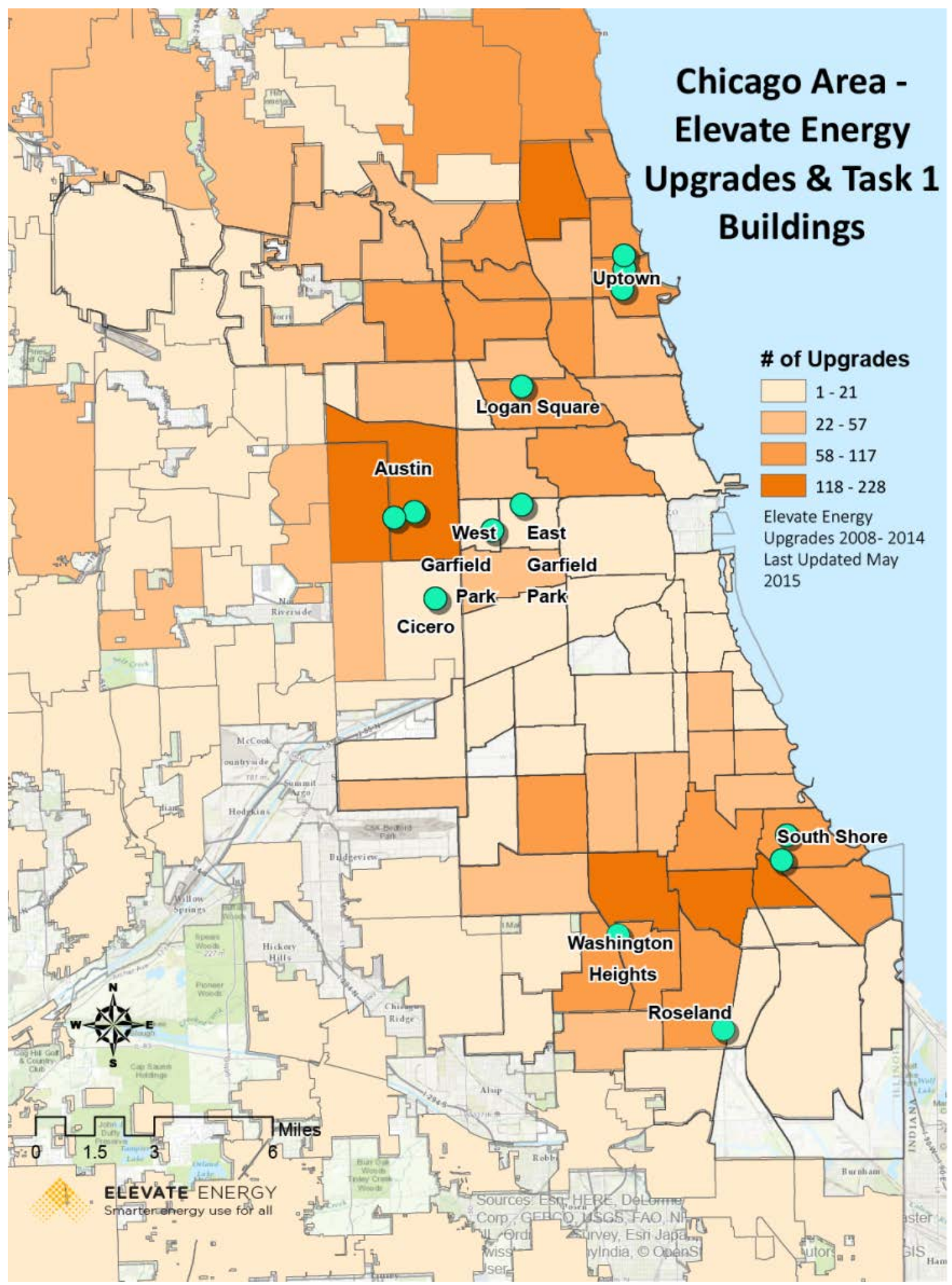


